\title{
New Zealand HR employee communication: Comparing 2000 and 2010 empirical results with forecasts for 2020
}

\begin{abstract}
Businesses in New Zealand demands high quality and cost effective products and services to remain locally and internationally competitive. This process includes competent managers and human resource (HR) practitioners who communicate effectively with staff. Empirical research was conducted in 2000 and again in 2010 and forecasted for 2020 to compare HR practitioners' traditional and contemporary communication modes such as Facebook, Twitter and Blogging with staff. Results were obtained via a mailed questionnaire in 2000 and obtaining a response of $10.1 \%$. An electronic questionnaire was used in 2010 and the response was 15.4\%. Recommendations are that HR staff could embrace HRIS' modern social media means in particular to enhance organisation communication to promote the competitiveness of organisations and staff satisfaction.
\end{abstract}

Keywords: HRM, employee engagement, job satisfaction, HRIS, retention, social media

\section{INTRODUCTION}

The contemporary work environment has changed significantly due to the development and application of new technology and use of electronic commerce (Nelson Quick Wright and Adams, 2012). Electronic human resource management (e-HRM) is also increasingly replacing traditional HRM roles. Nowadays, e-HRM such as human resource information systems (HRIS) has, amongst others, enabled HR practitioners to transform and transit from transactional and administration roles to being a strategic partner of the organisation (Martin and Reddington 2010; Tkalac Verčič Verčič and Sriramesh 2012).

The study conducted by Abdullah and Antony (2012) pointed out that employees view internal communication as part of the organisation's HRM responsibilities. HR practitioners become a middle person to obtain and disperse information regarding the HR strategy between management and employees. Hence selecting the appropriate channels of communication is becoming increasingly important.

In the globalised business world, electronic communication has also become very popular and highly preferred by employees (Ruck and Welch 2012; White Vanc and Stafford 2010; Welch 2012). Even though email is a highly preferred method of internal communication (Welch 2012), the Society for Human Resource Management (SHRM:2012b) and Deloitte (2011) stated that there is an increasing trend of using social media for staff communication in the workplace.

Social media is defined by SHRM (2011a, Para. 1) as "web-based tools and technologies used to share information and turn communication into interactive dialogue with internal and external audiences through Facebook, Linkedln and Twitter". 
HR practitioners play a significant role as a facilitator and a moderator using these media which would subsequently "restore some of the personal touch that was lost in previous pushes for improved HR efficiency" (Deloitte 2012:20).

\section{LITERATURE REVIEW}

Various theoretical aspects are presented in the literature regarding HR.

\section{HRIS and E-HR}

Martin and Reddington (2010:1553) developed a model of e-HR that focuses on the "relationship between HR strategy, e-HR goals and architecture, and positive and negative of e-HR outcomes". Their study also found that line managers believed that e-HR systems are off-loading HR duties to the managers to carry out staff administration tasks which subsequently increased their workload. Nelson et al. (2012:230-231) also claims that "new technologies are a double-edged sword that can be used to improve job performance or to create stress". The fast changing technologies could create techno-stress among the line managers and the employees. Nelson et al. (2012:231) went on to define techno-stress as "tension that is caused by the new and rapid technology changes that require workers to keep upto-date with the latest information technologies".

HR practitioners have to choose the proper message and channels to communicate and to promote advantages of using e-HR. The main benefit of e-HR is the ability to transform available knowledge and technology into a more strategically oriented function which addresses key success factors of an organisation in a timely manner for competitive advantage (Wilson 2010).

\section{Internal communication}

Staff should be informed about an organisation's current and future activities by building shared understanding of the overall business strategies. Abdullah and Antony (2012) found that employees who are fully informed about the organisation's goals are more satisfied at the workplace.

In this regard Welch (2012:250) found that the majority of the employees prefer to receive information about the organisation electronically rather than traditional printed formats. These findings are supported by White, Vanc and Stafford (2010) who found that employees prefer electronic information over traditional printed documents. Welch's (2012:252) also found that excessive and inappropriate internal communications could be "... a source of irritation to employees", because top-down communication using electronic media could portray an image of organisational power. HR practitioners have to carefully select, execute and maintain electronic communication in order to produce a positive impact on the workers and at the same time, encouraging employees to actively engage in social media that could be utilised as bottom-up communication tools. Marques (2010) also point out that employers should consider other circumstances such as demographics (age, 
ethnicity and social status) before selecting and evaluating the communication formats that are suitable for particular organisations.

Welch (2012) points out that the effectiveness of internal communication depends on the message and its format whether it is acceptable and useful to employees. HR practitioners also have to encourage and promote two-way communications in an organisation (top-down and bottom-up) so that the information relay is fair and effective. Employers are therefore in a position to utilise innovative ideas from employees to gain and maintain competitive advantage (Nel et al., 2012).

\section{Social media}

According to Deloitte $(2012: 20)$ “... social media has become standard business tools" rather than merely IT, as it can be used to share information among internal stakeholders. It also serves to integrate social media with HR service delivery and could transform the role of HRM in the workplace. Unfortunately, most organisations are reluctant to allow employees to use social media in the workplace (SHRM 2011b; NZ Herald 2012). Only $20 \%$ of the respondents from the SHRM (2012b) survey utilise social media as internal communications channels and $40 \%$ have social media policies in-place (SHRM 2012a). Employees view the creation and enforcement of the social media policy as a responsibility of HR Practitioners (SHRM 2012b).

\section{METHODOLOGY}

\section{Background to the collection of the empirical data}

The main research question is: What is the extent and use of communication means available to HR practitioners communicate with staff? The sub-question is to determine what the extent and use of contemporary social media is in communicating with staff.

A very comprehensive questionnaire covering 358 items to identify HRM and management trends was jointly compiled in New Zealand (NZ) and Australia in 1994. It was used for a survey to identify the future competencies and roles of HR in those countries for the year 2000 and was used by the then Institute of Personnel Management now known as the Human Resource Institute of New Zealand (IPMNZ 1994). That study formed the basis for subsequent research studies.

The questionnaire was edited and slightly modified and used in 2000 by Burchell (2001) in association with the (HRINZ) to determine a future perspective on human resources issues in 2000 and forecasted for 2010 in NZ. The minor modifications involved updating and reducing the questionnaire as it was too long and refining questions for clarity.

The questionnaire categories covered HR goals, roles and activities, as well as implications of changes in the business environment and finally identifying practices for gaining competitive advantage. Respondents were also asked to rank the five 
most important elements regarding goals, roles and activities in the various categories which were contained in the questionnaire. The final section of the said questionnaire sought to obtain demographic information from respondents.

The questionnaire was distributed to all members of the HRINZ. A total of 1510 questionnaires were mailed of which 150 usable responses were received, which represents $10 \%$ of the sample. After the responses were verified, the survey results were written up.

\section{Repeat study covering HR practice in New Zealand in 2010 forecasted for 2020}

The NZ study of 2000 was again used with minor modifications in 2010. It was clear from the previous studies' responses that the questionnaire was too detailed, which discouraged participation and the fact that it was paper-based. For the 2010 repeat study, the questionnaire was shortened, but some sections were again expanded to include contemporary aspects such as social media in the HRIS section. The reporting format was also changed to an e-survey using Survey Monkey. A 5-point Likert scale was also used which ranged from $1=$ "unimportant" to $5=$ "critical to success".

The target population was again limited to HRINZ members, but those who had registered to participate in HR research requests the HRINZ provided links to; the total number of HRINZ members in this category was 635. A total of 119 members responded but 98 questionnaires were fully completed and usable resulting in a $15.4 \%$ response rate.

Due to the growing importance of social media and e-HRM, the 2010 survey was expanded to include some questions on aspects such as the use of Facebook, Twitter and Blogging. This is in response to the importance of HR communication and e-HR which was identified in 2000 and forecasted for the 2010 survey.

Furthermore, due to the different reporting formats used in the different surveys namely from being merely listing and identifying priorities to a Likert Scale and an eformat for respondents, not all results are precisely comparable. However, trends previously identified are indicative of the present importance and context of the 2010 survey and forecasts for 2020 which are reported in this paper. It must be noted that due to the magnitude of the research projects and longitudinal nature thereof, only results focused on HR communication and e-HR and are reported on in this paper.

The similarity in the 2000 and 2010 surveyed profile of the respondents add value to the results as shown in the various tables. 
Table 1: Profile of respondents by profession in New Zealand in 2000 and 2010

\begin{tabular}{|l|c|c|}
\hline \multicolumn{1}{|c|}{ Profession } & $\begin{array}{c}\text { NZ } \\
\text { profile } \\
\mathbf{2 0 0 0}\end{array}$ & $\begin{array}{c}\text { NZ } \\
\text { profile } \\
\mathbf{2 0 1 0}\end{array}$ \\
\hline HR (officer to director) & $72.5 \%$ & $60.2 \%$ \\
\hline $\begin{array}{l}\text { Business (line } \\
\text { managers to CEO) }\end{array}$ & $10.1 \%$ & $1.4 \%$ \\
\hline Consultants & $13.8 \%$ & $24.7 \%$ \\
\hline $\begin{array}{l}\text { Academic (all tertiary } \\
\text { institutions) }\end{array}$ & $3.6 \%$ & $9.6 \%$ \\
\hline Other & $\mathbf{0 \%}$ & $4.1 \%$ \\
\hline TOTAL & $\mathbf{1 0 0 \%}$ & $\mathbf{1 0 0 \%}$ \\
\hline
\end{tabular}

In the current study in NZ (being 2010), the most frequent title was HR Manager (46.7\%), and the next most common title was HR non-management (16.7\%). Those two titles accounted for $60.2 \%$ of the reported titles compared to $72.5 \%$ in 2000 . There was high percentage of consultants in 2010 namely $24.7 \%$ versus $13.8 \%$ in 2000.

Table 2: Profile of respondents by organisation size in New Zealand in 2000 and 2010

\begin{tabular}{|c|c|c|}
\hline $\begin{array}{c}\text { Number of } \\
\text { employees in } \\
\text { organisation }\end{array}$ & $\begin{array}{c}\text { NZ profile } \\
\mathbf{2 0 0 0}\end{array}$ & $\begin{array}{c}\text { NZ } \\
\text { profile } \\
\mathbf{2 0 1 0}\end{array}$ \\
\hline Fewer than 10 & $1.0 \%$ & $12.5 \%$ \\
\hline $10-49$ & $3.9 \%$ & $6.9 \%$ \\
\hline $50-99$ & $8.6 \%$ & $4.2 \%$ \\
\hline $100-499$ & $40.4 \%$ & $26.4 \%$ \\
\hline 500 or more & $46.1 \%$ & $50 \%$ \\
\hline TOTAL & $\mathbf{1 0 0 \%}$ & $\mathbf{1 0 0 \%}$ \\
\hline
\end{tabular}

In NZ most organisations (83\%) have fewer than 10 employees. In this study, the participants are from different sized organisations as is shown in Table 2. The 
following groupings were compiled for analysis: small organisations with fewer than 10 and the various categories are also compatible. It should be noted that NZ is predominantly a country of small businesses, with $93.3 \%$ of enterprises employing 19 or fewer people ("SMEs in NZ: Structure and Dynamics" 2006).

\section{Table 3: Profile of the respondents by industry sector for 2000 and 2010}

\begin{tabular}{|l|c|c|}
\hline \multicolumn{1}{|c|}{ Sector } & $\begin{array}{c}\text { NZ profile } \\
\mathbf{2 0 0 0}\end{array}$ & $\begin{array}{c}\text { NZ profile } \\
\mathbf{2 0 1 0}\end{array}$ \\
\hline Agriculture, hunting, forestry and fishing & $4.2 \%$ & $4.3 \%$ \\
\hline Mining and quarrying & $1.4 \%$ & $1.5 \%$ \\
\hline Manufacturing & $5.5 \%$ & $6.9 \%$ \\
\hline Electricity, gas and water & $9.6 \%$ & $8.3 \%$ \\
\hline $\begin{array}{l}\text { Wholesale and retail trade, restaurants } \\
\text { and hotels }\end{array}$ & $5.0 \%$ & $6.2 \%$ \\
\hline Transport, storage and communication & $3.3 \%$ & $4.1 \%$ \\
\hline $\begin{array}{l}\text { Business, insurance and financial } \\
\text { services }\end{array}$ & $13.7 \%$ & $12.5 \%$ \\
\hline Community, social and personal service & $11.0 \%$ & $11.1 \%$ \\
\hline Education & $20.7 \%$ & $20.8 \%$ \\
\hline Other & $25.6 \%$ & $24.3 \%$ \\
\hline TOTAL & $\mathbf{1 0 0 \%}$ & $\mathbf{1 0 0 \%}$ \\
\hline
\end{tabular}

It is shown in table 2 that the results are comparable and 2000 results and forecasts for 2010 as well as the 2010 empirical results could be used for trends identification with confidence.

\section{Results of the survey}

The results of the 2010 e-survey and forecasts for 2020 regarding HR communication with staff re e-approaches are presented in Table 4. 


\section{Table 4: HR communication approaches with staff for 2010 and forecasted for 2020}

\begin{tabular}{|c|c|c|c|c|c|}
\hline Topic/Scale & $\begin{array}{l}1 \\
\text { Unimportant }\end{array}$ & $\begin{array}{l}2 \text { Slightly } \\
\text { important }\end{array}$ & $\begin{array}{l}3 \\
\text { Important }\end{array}$ & $\begin{array}{l}4 \text { Very } \\
\text { important }\end{array}$ & $\begin{array}{l}5 \text { Critical } \\
\text { to } \\
\text { success }\end{array}$ \\
\hline $\begin{array}{l}\text { The } \\
\text { organisation } \\
\text { has a human } \\
\text { resources } \\
\text { information } \\
\text { system }\end{array}$ & $\begin{array}{l}2010-9.7 \% \\
2020-1.4 \%\end{array}$ & $\begin{array}{l}2010- \\
18.1 \% \\
2020-5.6 \%\end{array}$ & $\begin{array}{l}2010- \\
29.2 \% \\
2020- \\
18.1 \%\end{array}$ & $\begin{array}{l}2010- \\
33.3 \% \\
2020- \\
38.9 \%\end{array}$ & $\begin{array}{l}2010- \\
9.7 \% \\
2020- \\
36.1 \%\end{array}$ \\
\hline $\begin{array}{l}\text { Internal } \\
\text { organisational } \\
\text { communication } \\
\text { is by electronic } \\
\text { means }\end{array}$ & $\begin{array}{l}2010-4.2 \% \\
2020-2.8 \%\end{array}$ & $\begin{array}{l}2010- \\
20.8 \% \\
2020- \\
11.1 \%\end{array}$ & $\begin{array}{l}2010- \\
36.1 \% \\
2020- \\
27.8 \%\end{array}$ & $\begin{array}{l}2010- \\
30.6 \% \\
2020- \\
33.3 \%\end{array}$ & $\begin{array}{l}2010- \\
8.3 \% \\
2020- \\
25.0 \%\end{array}$ \\
\hline $\begin{array}{l}\text { HR staff are } \\
\text { knowledgeable } \\
\text { about web } \\
\text { based services }\end{array}$ & $\begin{array}{l}2010-8.3 \% \\
2020-1.4 \%\end{array}$ & $\begin{array}{l}2010- \\
25.0 \% \\
2020- \\
5.6 \%\end{array}$ & $\begin{array}{l}2010- \\
45.8 \% \\
2020- \\
37.5 \%\end{array}$ & $\begin{array}{l}2010- \\
16.7 \% \\
2020- \\
36.1 \%\end{array}$ & $\begin{array}{l}2010- \\
4.2 \% \\
2020- \\
19.4 \%\end{array}$ \\
\hline $\begin{array}{l}\text { HR use of } \\
\text { Facebook to } \\
\text { communicate } \\
\text { with the staff }\end{array}$ & $\begin{array}{l}2010- \\
66.7 \% \\
2020- \\
34.7 \%\end{array}$ & $\begin{array}{l}2010- \\
22.2 \% \\
2020- \\
25.0 \%\end{array}$ & $\begin{array}{l}2010- \\
9.7 \% \\
2020- \\
19.4 \%\end{array}$ & $\begin{array}{l}2010- \\
1.4 \% \\
2020- \\
15.3 \%\end{array}$ & $\begin{array}{l}2010- \\
0.0 \% \\
2020- \\
5.6 \%\end{array}$ \\
\hline $\begin{array}{l}\text { HR use of } \\
\text { Twitter to } \\
\text { communicate } \\
\text { with the staff }\end{array}$ & $\begin{array}{l}2010- \\
77.8 \% \\
2020- \\
45.8 \%\end{array}$ & $\begin{array}{l}2010- \\
12.5 \% \\
2020- \\
25.0 \%\end{array}$ & $\begin{array}{l}2010- \\
9.7 \% \\
2020- \\
12.5 \%\end{array}$ & $\begin{array}{l}2010- \\
0.0 \% \\
2020- \\
12.5 \%\end{array}$ & $\begin{array}{l}2010- \\
0.0 \% \\
2020- \\
4.2 \%\end{array}$ \\
\hline $\begin{array}{l}\text { HR use of } \\
\text { blogging to } \\
\text { communicate } \\
\text { with the staff }\end{array}$ & $\begin{array}{l}2010- \\
54.2 \% \\
2020- \\
22.2 \%\end{array}$ & $\begin{array}{l}2010- \\
27.8 \% \\
2020- \\
23.6 \%\end{array}$ & $\begin{array}{l}2010- \\
15.3 \% \\
2020- \\
33.3 \%\end{array}$ & $\begin{array}{l}2010- \\
2.8 \% \\
2020- \\
13.9 \%\end{array}$ & $\begin{array}{l}2010- \\
0.0 \% \\
2020- \\
6.9 \%\end{array}$ \\
\hline $\begin{array}{l}\text { HR use of } \\
\text { Linkedin to } \\
\text { communicate } \\
\text { with the staff }\end{array}$ & $\begin{array}{l}2010- \\
58.3 \% \\
2020- \\
20.8 \%\end{array}$ & $\begin{array}{l}2010- \\
20.8 \% \\
2020- \\
36.1 \%\end{array}$ & $\begin{array}{l}2010- \\
19.4 \% \\
2020- \\
20.8 \%\end{array}$ & $\begin{array}{l}2010- \\
1.4 \% \\
2020- \\
16.7 \%\end{array}$ & $\begin{array}{l}2010- \\
0.0 \% \\
2020- \\
5.6 \%\end{array}$ \\
\hline
\end{tabular}


Test results to determine significance differences between 2010 and 2020 responses are presented in Table 5.

Table 5: Paired comparisons and significance of results

\begin{tabular}{|c|c|c|c|c|}
\hline $\begin{array}{l}\text { Pair } \\
\text { number }\end{array}$ & Question & $\begin{array}{l}\text { Mean } \\
2010\end{array}$ & $\begin{array}{l}\text { Mean } \\
2020\end{array}$ & Significance \\
\hline 1 & $\begin{array}{l}\text { The organisation has a human } \\
\text { resources information system }\end{array}$ & 3.12 & 4.00 & $\begin{array}{l}.000^{*} \\
1.000^{* *}\end{array}$ \\
\hline 4 & $\begin{array}{l}\text { Internal organisational } \\
\text { communication is by electronic } \\
\text { means }\end{array}$ & 3.28 & 3.78 & $\begin{array}{l}.000^{\star} \\
1.000^{\star *}\end{array}$ \\
\hline 13 & $\begin{array}{l}\text { HR staff are knowledgeable about } \\
\text { web based services }\end{array}$ & 2.83 & 3.65 & $\begin{array}{l}.000^{*} \\
1.000^{\star *}\end{array}$ \\
\hline 16 & $\begin{array}{l}\text { HR use of Facebook to } \\
\text { communicate with the staff }\end{array}$ & 1.48 & 2.40 & $\begin{array}{l}.000^{*} \\
1.000^{* *}\end{array}$ \\
\hline 17 & $\begin{array}{l}\text { HR use of Twitter to communicate } \\
\text { with the staff }\end{array}$ & 1.35 & 2.12 & $\begin{array}{l}.000^{*} \\
1.000^{* *}\end{array}$ \\
\hline 18 & $\begin{array}{l}\text { HR use of blogging to communicate } \\
\text { with the staff }\end{array}$ & 1.67 & 2.60 & $\begin{array}{l}.000^{*} \\
1.000^{* *}\end{array}$ \\
\hline 19 & $\begin{array}{l}\text { HR use of Linkedin to communicate } \\
\text { with the staff }\end{array}$ & 1.68 & 2.62 & $\begin{array}{l}.000^{*} \\
1.000^{* *}\end{array}$ \\
\hline
\end{tabular}

${ }^{*} p<0.01$ (Note: Scale used was: 1-Unimportant, 5- Critical to success)

** Wilcoxon Signed Ranks Test

The results of the e-survey were subject to verification for SPSS analysis purposes. The Likert Scale application (ranging from 1-Unimportant to 5- Critical to success) for the 2010 survey enabled the researchers to apply statistical analyses which were not possible for the 2000 survey. Parametric and non-parametric tests were applied using the Wilcoxon Signed Ranks Test as well. Significance levels at the $p<0.01$ were recorded.

It must be noted that relevant results from the 2000 and forecasts for 2010 study are compared with the current results (that is 2010 and forecasted for 2020).

\section{FINDINGS AND DISCUSSION}

To communicate with staff, HR ought to operate a comprehensive HRIS. This would provide the backdrop for the various means to communicate across various functional areas with staff. These aspects, as presented in the survey results, are discussed by topic in this section.

\section{The organisation has a HRIS}

In 2010 it was clear that a high degree of support existed for a HRIS system and $9.7 \%$ rated it as critical. However, compared to 2020 there is much more support 
regarding it being critical to success and the response jumped to $36.1 \%$. This result is significant at the $p<0.01$ level as shown in Table 5 . It can be deduced that in future much more emphasises is to be placed on HRIS.

According to Burchell and Beaver (2005:10) the 2000 survey with forecasts for 2010 rated HRIS as the $7^{\text {th }}$ most important priority by HR staff for 2010 with a $32.2 \%$ response to the following question: What priority should the activity have in the year $2010 ?$

\section{Internal organisational communication by electronic means}

The results for 2010 reveal that the importance as high, bearing in mind that $30.6 \%$ of respondents rated it as very important and $8.3 \%$ as critical to success. For 2020 the response is $33.3 \%$ for very important and $25 \%$ for critical to success. This trend is supported in the literature by Oiry (2009) who emphasises the growth of E-HRM processes. The result is significant at the $p<0.01$ level as shown in Table 5 . It can be deduced that in future more extensive communication by electronic means would become even more critical for organisations to communicate effectively with staff.

In the 2000 survey it was already on the priority list. According to Burchell and Beaver (2005:10) the 2000 survey with forecasts for 2010 rated employer and employee internal communication as the $6^{\text {th }}$ most important priority by HR staff for 2010 with a $37.2 \%$ of respondents in response to the following question: What priority should the activity have in the year 2010? It is even higher than HRIS priority at that point in time.

A further question in the 2000 survey focussed on whether respondents believed that there would be present and future benefits of HRIS to organisations regarding employer and employee communication. The results were that for 2000 only $12.5 \%$ of respondents saw benefits, but it increased spectacularly to $61.9 \%$ for 2010 (Burchell and Beaver, 2005:20). It is clear that over time employer and employee communication's importance increased dramatically and supports the current trend as was originally identified by Burchell (2002).

\section{HR staff is knowledgeable about web based services}

In 2010 the level of knowledge of HR staff about web-based services was quite low in that $8.3 \%$ regarded it as unimportant and $25 \%$ as slightly important, thus being a third of all respondents. This is contrasted by the forecast for 2020 where $1.4 \%$ rated it as unimportant and $5.6 \%$ as slightly important to success. There is consequently a large change in emphasis from 2010 to 2020 regarding HR being knowledgeable about websites.

The result is significant at the $p<0.01$ level as shown in Table 5 . The future value of web-based services has become undeniably important for HR staff as a crucial element of their function. Various web-based services are critical for the future which is highlighted in the literature survey by various researchers ( $\mathrm{Nel}$ et al. 2012; Oiry 2009). 
Once again the forerunner to current aspects relating to websites and related aspects can be traced back to the 2000 and forecasts for 2010 survey identified by Burchell and Beaver (2005:21). It was reported that nearly $85 \%$ of organisations had their own website in 2000. All the organisations were planning to have their own website by 2010. The HR departments were slower to set up their own websites in 2000 with only $27 \%$ already having their own sites, but the respondents anticipated a dramatic increase to $82 \%$ having their own website by 2010 .

\section{HR use of Facebook to communicate with the staff}

The result for the new 2010 survey question re the use of Facebook is quite surprising for 2010 in that $88.9 \%$ of the HR respondents (unimportant and slightly important combined) allocated such a low usage to Facebook as a communication means with staff. Furthermore, the forecast for 2020 also has $59.7 \%$ of respondents as a low response (unimportant and slightly important combined) regarding communicating with staff.

The result is significant at the $p<0.01$ level as shown in Table 5 . It is deduced that although a low positive response rate was recorded, the significance over a 10 year period is huge and that organisations ought to pay much more attention to Facebook to communicate with staff. As generation $Y$ and $X$ increase in the workplace, this communication means might expand much more than is anticipated which is emphasised by Deloitt (2011) as well as Nel et al. (2012) in the literature survey. The NZ Herald (2012) report also confirms that Facebook use in organisations is popular.

\section{HR use of Twitter to communicate with the staff}

The use of Twitter as a new 2010 survey question, which has only recently become a high use means of communication, has increased phenomenally as evidenced by celebrities' followers and their communication via Twitter by way of example. The following of megastars in the entertainment world via Twitter communication have peaked in the millions in the last couple of years when newsworthy occurrences have been publicised involving celebrities.

It is, however, surprising that the response rate for the use of Twitter in HR communication with staff is regarded as unimportant or slightly important by $90.3 \%$ of the respondents. The forecasted response for 2020 is also a surprising $70.8 \%$ (unimportant or slight important). However, the response difference between 2010 and 2020 is significant and needs to be investigated in more detail.

The result is significant at the $p<0.01$ level as shown in Table 5 . It can once again be deduced that this communications means should not be under estimated, as Generation $\mathrm{Y}$ and $\mathrm{X}$ will play an ever increasing and significant role in organisations in future.

\section{HR use of Blogging to communicate with the staff}

This result (as a new 2010 survey question) is also surprising in that for 2010 a total of $82.0 \%$ of the respondents regard Blogging as unimportant or slightly important. 
The result is also different for the forecast for 2020 being $45.8 \%$ (unimportant or slightly important combined), but is significant. The trend for the use of ultra-modern communication means by $\mathrm{HR}$ to communicate with employees is clearly not yet common place.

The result is significant at the $p<0.01$ level as shown in Table 5 . It is deduced that more organisations will have to gear themselves to use Blogging as a means to communicate in future, as the significance level of the result indicate.

\section{HR use of LinkedIn to communicate with the staff}

Linkedln as a means of communication (as a new 2010 survey question) has become popular amongst particularly skilled employees at all employment levels across industries and professions. The results for 2010 are, however, surprisingly low for HR to use it as a means to communicate with staff being $79.1 \%$ (unimportant or slightly important combined) compared to the forecast for 2020 , which is still low, albeit significant compared to 2010 . The result for 2020 was $56.9 \%$ (unimportant or slightly important combined).

The result is significant at the $p<0.01$ level as shown in Table 5 . This significance clearly indicates that this approach should be carefully taken note of for the future and although it is still far below being important, it should not be under estimated as a tool for HR to use in future.

\section{IMPLICATIONS OF THE FINDINGS}

The results from this empirical longitudinal study showed that social media are not yet considered as important channels of communication by HR with staff. It is perhaps not prudent to believe that social media may become as popular as e-mail as an internal organisational communication tool in future.

HR staff has to fully utilise skills and knowledge of the web-based information to apply e-via HRM, HRIS and social media as internal communications in the workplace in future. This must also be viewed in the light of employees' perceptions that open communication leads to staff satisfactions, as they believe that bottom-up, top-down and horizontal communication enhance relationship between workers and management (Abdullah and Antony 2012; Strack et al. 2008; Welch 2012).

Social media can also be used in instantly updating staff with the latest information on organisations' current events, change of policies, achievements and any other issues related to their jobs, industry or competitors. Abdullah and Antony (2012) argued that timely disperse of the information would make employees feel valued by the organisation, which would subsequently increase job satisfaction. Social media could therefore transform HRM roles in the organisation by being a facilitator as well as moderator of the information published in the social media channels (Deloitte 2012). 


\section{CONCLUSION}

It is clear from the results that contemporary social media communication by HR staff has not gained as much popularity as would have been expected. However, the differences between the 2000, as well as 2010 results compared to 2020 are significant and noteworthy. HR departments and those functionaries executing the task of regularly communicating with staff therefore ought to take note that a rapid change in communication means is taking place, as highlighted by various researchers (Strack et al. 2008; Nel Du Plessis and Josefino 2011).

Contemporary communication means such as Facebook, Twitter and blogging could perhaps become centre stage in future to communicate with the ever younger and electronic au fait personnel in organisations, since the baby boomer generation numbers are currently rapidly increasing their exit from organisations. Generation $Y$ is familiar with this means of communication via the availability of personal electronic equipment such as iPhones and iPads. To use social media are becoming an ever more popular means of communication in and outside of organisations (Deloitte 2011).

The landscape of HR communication is therefore anticipated to change noticeably in the foreseeable future for employer and employee communication. This includes social media, as was shown in the results of this empirical research in NZ. Further research could focus on a particular industry as well as the age profile and occupational position of staff. In other words, to reverse the research focus and obtain empirical data from staff regarding their preferred communication means with them by the HR department. Finally, it is very likely that even greater involvement in technology systems that enhance communication as well as social media usage in HR's activities, will be the order of the day in future HR practise, as was identified by the longitudinal empirical research reported in this paper. Is HR staff ready for social media's future use is probably currently the million dollar question. 


\section{REFERENCES}

Abdullah Z and Antony CA 2012, Perception of employees on internal communication of a leading five star hotel in Malaysia, Asian Social Science 8(2): 17-26. doi:10.5539/ass.v8n2p17

Burchell N and Beaver R 2005, Consolidated report on human resources priorities for competitive advantage in New Zealand from 2000 to 2010, The IPM Survey Report, New Zealand, Unitec.

Burchell N 2001, 2000 to 2010 future directions for HR in New Zealand, Presentation to the annual conference of the Human Resources Institute of New Zealand, Wellington, September.

Burchell N 2002, 1994 to 2010 Future directions for HR in New Zealand, New Zealand, Unitec.

http://www/hrinz.org.nz/info/hot stuff/conference/noel burchell.asp Date accessed: 10 November 2011.

Deloitte 2011, Enabling HR service delivery, Retrieved from http://www.deloitte.com/assets/DcomGlobal/Local\%20Assets/Documents/global cons JourneytoHRT SocialNetworkin g 120811.pdf

Deloitte 2012, Social mobile at work: Human capital trends 2012. Retrieved from http://www.deloitte.com/view/en US/us/Services/consulting/human-capital/humancapital-trends-2012/cc78248d88185310VgnVCM3000001c56f00aRCRD.htm

Institute of Personnel Management New Zealand (IPMNZ) 1994, Human resources priorities for competitive advantage 1994-2000, The IPM survey report, Auckland, New Zealand, Institute of Personnel Management New Zealand.

Martin G and Reddington M 2010, Theorizing the links between e-HR and strategic HRM: a model, case illustration and reflections, International Journal of Human Resource Management, 21(10): 1553-1574. doi:10.1080/09585192.2010.500483.

Marques JF 2010, Enhancing the quality of organizational communication: A presentation of reflection-based criteria, Journal of Communication Management 14(1): 47-58. doi:10.1108/13632541011017807.

Nel PS, Werner A, Du Plessis AJ, Fazey M, Erwee R, Pilay S, Hearn Mackinnon B, Millett B and Wordsworth R 2012, Human resource management in Australia and New Zealand. Melbourne, Australia: Oxford University Press.

Nel PS, Du Plessis AJ and San Diego J 2011, Management implications for managers and HR practitioners: some longitudinal research findings in New Zealand, Asia Pacific Journal of Business and Management, July - December 2(2): $60-73$,

Nelson DL, Quick JC, Wright S and Adams C 2012, ORGB. Australia: Cengage Learning Australia Pty Limited. 
NZ Herald. 2012, One in five kiwis 'like' Facebook use at work. NZ Herald, http://www.nzherald.co.nz/news/print.cfm?objectid=10813136 Accessed on 15 June, 2012.

Oiry E 2009, Electronic human resource management: Organizational responses to role conflicts created by e-learning, International Journal of Training and Development 13(2): 111-123.

Ruck K and Welch M 2012, Valuing internal communication: Management and employee perspectives, Public Relations Review 38(2): 294-302. doi:10.1016/j.pubrev.2011.12.016.

SHRM 2011a, November. SHRM research spotlight: Social networking websites and staffing. Retrieved from http://www.shrm.org/Research/SurveyFindings/Documents/Social\%20Networking \%20Flyer Staffing\%20Conference FINAL1.pdf

SHRM 2011b, November. SHRM survey findings: Social media in the workplace. Retrieved from http://www.shrm.org/Research/SurveyFindings/Documents/Part\%203_Social_Net working_Media_Flier_FINAL.pdf.

SHRM 2012a, January. SHRM research spotlight: Social media in business strategy and operations. Retrieved from

http://www.shrm.org/Research/SurveyFindings/Documents/Part 4 Social Media Flier.pdf.

SHRM 2012b, January. SHRM survey findings: An examination of how social media is embedded in business strategies and operations. Retrieved from http://www.shrm.org.

SMEs in New Zealand: Structure and Dynamics 2006, Retrieved 10 September 2011, from http://www.med.govt.nz/

Strack R, Dyer A, Cay J, Minto A, Leicht M and Francoeur F 2008, Creating people advantage: How to address HR challenges worldwide through 2015, USA: Boston Consulting Group: World Federation of Personnel Management Association.

Tkalac Verčič A, Verčič D and Sriramesh K 2012, Internal communication: Definition, parameters and the future Public Relations Review 38(2): 223-230.

doi:10.1016/j.pubrev.2011.12.019

Welch M 2012, Appropriateness and acceptability: Employee perspectives of internal communication, Public Relations Review 38(2): 246-254.

doi:10.1016/j.pubrev.2011.12.017

White C, Vanc A and Stafford G 2010, Internal communication, information satisfaction, and sense of community: The effect of personal influence, Journal of Public Relations Research 22(1): 65-84. doi:10.1080/10627260903170985.

Wilson P 2010, People@work/2020: Challenges and issues for Australian HR practitioners, Australian Human Resources Institute. 